$10-8-2021$

\title{
Book Review: It Can Happen Here: White Power and the Rising Threat of Genocide in the US
}

Jeffrey Bachman

American University

Follow this and additional works at: https://digitalcommons.usf.edu/gsp

\section{Recommended Citation}

Bachman, Jeffrey (2021) "Book Review: It Can Happen Here: White Power and the Rising Threat of Genocide in the US," Genocide Studies and Prevention: An International Journal: Vol. 15: Iss. 2: 49-51. DOI:

https://doi.org/10.5038/1911-9933.15.2.1842

Available at: https://digitalcommons.usf.edu/gsp/vol15/iss2/7

This Book Review is brought to you for free and open access by the Open Access Journals at Digital Commons @ University of South Florida. It has been accepted for inclusion in Genocide Studies and Prevention: An International Journal by an authorized editor of Digital Commons @ University of South Florida. For more information, please contact digitalcommons@usf.edu. 


\title{
Book Review: It Can Happen Here: White Power and the Rising Threat of Genocide in the US
}

\author{
Jeffrey Bachman \\ American University School of International Service \\ Washington, D.C., U.S.A.
}

It Can Happen Here: White Power and the Rising Threat of Genocide in the US

Alexander Laban Hinton

New York, New York University Press, 2021

304 Pages; Price: \$29.00 Hardcover

Reviewed by Jeffrey Bachman

American University School of International Service

Well-known by most for his research in Cambodia, as well as his testimony before the Extraordinary Chambers in the Courts of Cambodia (ECCC), in It Can Happen Here: White Power and the Rising Threat of Genocide in the US, Alex Hinton impeccably weaves public anthropology, history, comparative and critical genocide studies, and pedagogy into a tapestry that alternates between the historical, the present, the classroom, and the future. Nevertheless, when writing a review of a book like Hinton's, it can be difficult to identify where to begin and what to foreground because it is a unique tour de force comprising many parts that speak to many audiences-academics, students, policymakers, and the general public. Indeed, in addition to this review and those by other scholars, Kirkus Reviews describes It Can Happen Here as a "wellresearched," "deeply relevant," "tremendously timely," and "readable account."1

Perhaps, as a starting point, I should note what It Can Happen Here is not. Though former President Donald Trump plays a leading role throughout, Hinton's book is neither exclusively about Trump and his America, nor is it one that proclaims Trump to be a fascist ideologue. Hinton is far too critical and reflective to rely on such easy and signaling tropes. Hinton, instead, highlights Trump's connections to and reliance on ideological actors, noting that his "path to power was very much intertwined with demagoguery, hate speech, the demonization of nonwhite others, and the increased visibility of neofascists and other white power actors who supported him." 2

To be clear, Hinton does not understate the seriousness of Trump's deployment of white power rhetoric, both veiled and explicit. As Hinton writes, "[Trump] pandered to white power interests, a situation that could have had disastrous consequences-even genocidal ones-if circumstances had fully aligned." 3 Ultimately, this is what It Can Happen Here is about. It considers whether genocide can happen in the U.S.A, as well as how it can be prevented. Significantly, it does so without overlooking the forest for the trees by seeing Trump and current manifestations of white power as symptoms of the history of white power and associated violences perpetrated against persons and communities of color, in particular Indigenous North Americans and Africans forced into slavery, and their descendants, as well as Jewish communities.

\footnotetext{
1 "It Can Happen Here: White Power and the Rising Threat of Genocide in the US," Kirkus Reviews, May 13, 2021, accessed September 1, 2021, https://www.kirkusreviews.com/book-reviews/alexander-laban-hinton/it-canhappen-here/.

2 Alexander Laban Hinton, It Can Happen Here: White Power and the Rising Threat of Genocide in the US (New York: New York University Press, 2021), 13.

${ }^{3}$ Ibid., 16.
}

Jeffrey Bachman. "Book Review: It Can Happen Here: White Power and the Rising Threat of Genocide in the US." Genocide Studies and Prevention 15, no. 2, 49-51. https://doi.org/10.5038/1911-9933.15.2.1842.

(c) 2021 Genocide Studies and Prevention. 
As becomes clear throughout his book, critical thinking, analysis, and reflection are practices that Hinton demands of himself and his students. A central question Hinton poses throughout is: "What makes a man start fires?" It is in addressing the question of what makes a person participate in different forms of group-based violence that Hinton seamlessly moves between historical accounts, his anthropological research in Cambodia and the U.S., making comparisons therein that illuminate the potential for mass atrocities in the U.S., and his engagement with students in his classroom.

"What makes a man start fires?" is also Hinton's "why" question, which is essential to his critical pedagogy and use of the Socratic method. Hinton explains that the Frankfurt School and its method of critique provide:

a way to take up not just identity issues like race, ethnicity, class, and gender but also phenomena such as colonialism, capitalism, bureaucracy, mass media, and so forth. For Horkheimer, Adorno, and the Frankfurt School, critique was emancipatory, providing a pathway to self-awareness, autonomy, and, when necessary, resistance. ${ }^{4}$

This brings us to "the snake" and "the bird"-bookends to Hinton's It Can Happen Here. "The Snake," a song written and first recorded by civil-rights activist Oscar Brown, and popularized by Al Wilson, was perverted by Trump during 2016 campaign rallies to stir antiimmigrant sentiments. Hinton writes that "'The Snake' can be directly read as a parable regarding the danger of white genocide replacement by immigrants." ${ }^{5}$ Hinton concludes his book by counterposing Trump's appropriation of "The Snake" with Toni Morrison's "bird" of language. As Hinton explains, Morrison emphasized how language, when used in an ethically responsible manner, "can be emancipatory and stand against structures of domination, especially racism." 6

To achieve critical self-awareness, what we do with answers to the "why" question is more important than the question itself. In his research and his teaching, Hinton goes beyond simply posing the question; he challenges his students to interrogate their presuppositions, history, media narratives, political messaging, symbols, and so on. In doing so, Hinton seeks to move his students beyond understandings that are based predominantly on opinion to a deeper recognition of the complex processes that connect present day manifestations of hate, prejudice, bigotry and violence to their historical roots. Yet, in moving from opinion to interrogation, from the simple to the complex, Hinton does not require detachment when emotions are strong and lived experiences are intertwined.

It is clear that Hinton's objective is not emotional detachment, but rather a recognition that the simple answers and explanations are always there, lying in wait, ready to be deployed. As Hinton writes, in relation to a discussion about Charlottesville that he had with his class, "The Hater lurks everywhere during our class."7 Other terms that were used to describe Chris Cantwell, also known as the "Crying Nazi" include "crazy," "demented," "racist," and "twisted." These simple answers, however, can sometimes be the easy product of the question of "what makes a man start fires?" because, Hinton explains, "It directs us to focus on individual intention and look away from the structures that mediate human agency, including the forces of power and history." 8

It is in Hinton's and his students' exploration and interrogation of the paths that lead away from the simple answers that It Can Happen Here really shines. It simultaneously offers

\footnotetext{
${ }^{4}$ Ibid., 29.

5 Ibid., 185.

${ }^{6}$ Ibid., 217.

7 Ibid., 54 .

8 Ibid., 71.
} 
inspiration for others to employ a more critical pedagogy in the classroom, while also contributing to critical genocide studies, an approach to the study of genocide that can be traced back to Dirk Moses and Hinton. ${ }^{9}$ At a time when the primary critique of the U.S. remains that it is too often a bystander to genocide, Hinton confronts the current situation in the U.S., centers its history, and draws what is not necessarily a straight line, but one that nonetheless links U.S. history, including its genocidal origins and slavery, to its present.

The forgotten or ignored We Charge Genocide: The Crime of Government Against the Negro People petition is a text referenced throughout Hinton's book. By incorporating it, Hinton recognizes what few other genocide scholars seem willing to do:

the plight of Blacks in the United States at the time of the We Charge Genocide petition, particularly in the Jim Crow South, could arguably be viewed as part of a long-term genocidal process—one that also involved crimes against humanity.10

Hinton doesn't stop at Jim Crow, adding that "the current situation of Blacks-as well as Native Americans-could arguably be considered an ongoing genocide, particularly if one takes a long-duration perspective." 11 Of course, Hinton does not suffer from naivety. He recognizes that many genocide scholars would disagree. However, he counters that the possibility of ongoing genocides in the U.S.

is at least an in-depth conversation the field must have and that the field needs to be critically rethought in light of systemic white supremacy and the Holocaust prototype assumptions that inform much of its research. ${ }^{12}$

Even if not ongoing genocide, Hinton shows in his research and engagement with his students that the "rising threat of genocide in the US" is more than a subtitle. If genocide is viewed as a puzzle, with perpetration commencing when the puzzle is complete, many of the pieces are already in place and there are individuals and groups looking to place more pieces by peddling in the fear of "white genocide" and the idea of "great replacement."13

In confronting a widely held American exceptionalist belief that genocide is something that happens elsewhere and that, when it does, U.S. sin is not doing enough to prevent it, there may have been a missed opportunity in It Can Happen Here to challenge orthodoxy even further. This could have been achieved by broadly connecting racism and white power to a history of atrocities committed by the U.S. beyond its borders, particularly against people of color residing in the Global South, as well as those committed by client states with U.S. knowledge and support, as in the case of Indonesia in 1965.

The above critique must be viewed as a minor one, as U.S. foreign policy was not a focus of Hinton's incredibly important book. In It Can Happen Here, Hinton matches academic rigor with popular accessibility, making it a must read for academics, students, and the general population alike.

\footnotetext{
9 See A. Dirk Moses, "Toward a Theory of Critical Genocide Studies," Mass Violence and Resistance Research Network, accessed May 1, 2019, http://www.sciencespo.fr/massviolence-war-massacre-resistance/en/document/towardtheory-critical-genocide-studies; Alexander Laban Hinton, "Critical Genocide Studies," Genocide Studies and Prevention 7, no. 1 (2012), 4-15.

${ }^{10}$ Hinton, It Can Happen Here, 142.

${ }^{11}$ Ibid., 232.

12 Ibid.

${ }^{13}$ Ibid., 183.
} 